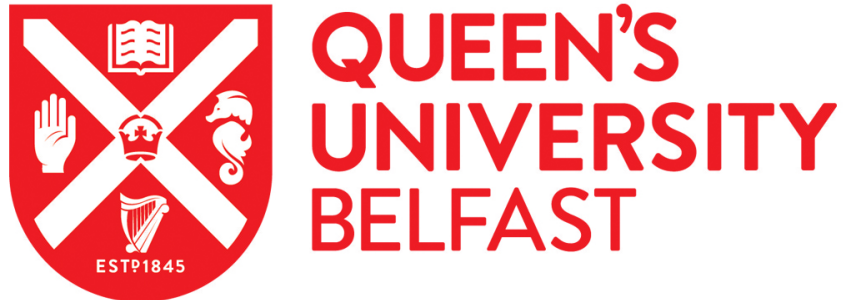

\section{Can diversity promote trust? Neighbourhood context and trust in the police in Northern Ireland}

Bradford, B., Topping, J., Martin, R., \& Jackson, J. (2018). Can diversity promote trust? Neighbourhood context and trust in the police in Northern Ireland. Policing and Society, 29(9), 1022.

https://doi.org/10.1080/10439463.2018.1479409

\section{Published in:}

Policing and Society

\section{Document Version:}

Peer reviewed version

Queen's University Belfast - Research Portal:

Link to publication record in Queen's University Belfast Research Portal

\section{Publisher rights}

(c) 2018 Informa UK Limited, trading as Taylor \& Francis Group. This work is made available online in accordance with the publisher's policies. Please refer to any applicable terms of use of the publisher.

\section{General rights}

Copyright for the publications made accessible via the Queen's University Belfast Research Portal is retained by the author(s) and / or other copyright owners and it is a condition of accessing these publications that users recognise and abide by the legal requirements associated with these rights.

Take down policy

The Research Portal is Queen's institutional repository that provides access to Queen's research output. Every effort has been made to ensure that content in the Research Portal does not infringe any person's rights, or applicable UK laws. If you discover content in the Research Portal that you believe breaches copyright or violates any law, please contact openaccess@qub.ac.uk. 


\section{Can diversity promote trust? Neighbourhood context and trust in the police in Northern Ireland}

Ben Bradford, Jill Dando Institute of Security and Crime Science, UCL, London

John Topping, Queen's University, Belfast

Richard Martin, Centre for Criminology, University of Oxford

Jonathan Jackson, Methodology Department, London School of Economics

Corresponding author: Dr John Topping, 6 College Park, Queen's University, Belfast, BT7 1LP email: j.topping@qub.ac.uk telephone: 02890973630 twitter: @drjohntopping

Ben Bradford is Director of the Institute for Global City Policing at the UCL Jill Dando Institute of Security and Crime Science. His research interests include procedural justice theory, public trust, and police legitimacy. His book, Stop and Search and Police Legitimacy, was published in 2017; he is also editor, along with Beatrice Jauregui, Ian Loader and Jonny Steinberg, of the SAGE Handbook of Global Policing (2016).

John Topping is a lecturer in criminology at Queen's University, Belfast and Fellow of the Senator George J. Mitchell Institute for Global Peace, Security and Justice. His research interests centre around police reform, practice, and accountability, along with stop and search and public order policing. He has over a decade of research and consultancy experiences with all the policing institutions in Northern Ireland and is currently Chairperson of Community Restorative Justice Ireland.

Richard Martin is based at the Centre for Criminology at the University of Oxford. He research interests include policing, human rights and procedural justice, with particular reference to Northern Ireland. He has extensive experience in the wider criminal justice field, including consultancy for the Law Commission of England and Wales. He is also a Fellow at the London School of Economics.

Jonathan Jackson is a Professor of Research Methodology at the London School of Economics. He is a member of the Manheim Centre for Criminology, the Criminal Law and Criminal Justice Theory Forum, and the Behavioural Sciences Hub. Jon is an editor of the British Journal of Criminology. 
Can Diversity Promote Trust? Neighbourhood Context and Trust in a Divided Police Setting

Ben Bradford, UCL Jill Dando Institute of Security and Crime Science

John Topping, Queen's University Belfast

Richard Martin, Centre for Criminology, University of Oxford

Jonathan Jackson, Methodology Department, London School of Economics 


\begin{abstract}
The association between trust in the police and neighbourhood context is well known. Police seem to enjoy more trust when community settings are perceived as orderly, cohesive and well-functioning, and trust seems to be lower when order and cohesion seem attenuated or under threat. Yet, little attention has been paid to the association between neighbourhood diversity and trust in the police. Allport's contact hypothesis suggests that because diversity increases intergroup contact and thus a sense of cohesion, it may promote trust in the police. We use data from a nationally representative survey conducted in 2014, combined with Census and other localarea data, to explore the association between ethno-religious diversity and trust in the Police Service of Northern Ireland. We find that trust is higher in more diverse areas, primarily because Catholics living in such areas report significantly higher levels of trust than their counterparts living in less diverse areas. We interpret these results in light of what policing means in contemporary Northern Ireland, almost two-decades after the country's landmark reform of policing began.
\end{abstract}

Keywords: Police Service of Northern Ireland; diversity; confidence; police-community relations

\title{
Introduction
}

The association between neighbourhood or community context and trust in the police is well established (e.g. Brown and Benedict 2002; Bradford and Myhill, 2015, Cao et al. 1996, Sampson and Bartusch 1998, Jackson and Bradford 2009, Kwak and McNeeley 2017). Across diverse contexts, the objective and subjective characteristics of peoples' immediate social environments appear to be important predictors of their willingness to trust police — an institution charged with regulating those environments. This article explores how trust in the Police Service of Northern Ireland (PSNI) is intertwined with locality, community identity, and diversity. Northern Ireland (NI), where trust in the police is closely bound up with the armed conflict that lasted for thirty years (Mulcahy 2006) and where segregation and marginalisation continue to affect its communities, provides a novel environment in which to address such issues.

Major post-conflict police reform has institutionalised a new community and human rights based approach to policing in NI, yet relations between police and certain communities remain strained due to the history of the conflict and ongoing tensions (particularly in deprived areas: Byrne \& Monaghan, 2008, Ellison, 2000, Ellison et al. 2012). At the aggregate level, trust in police differs little between Protestants and Catholics and is remarkably high. Figure 1 plots results from a series of surveys conducted by the Northern Ireland Policing Board (NIPB) over recent years, and while Protestants score consistently higher in terms of the 'job rating' for local police, the gap is not large. But more local research paints a different picture. In Ellison et al's (2012) study of a working class Republican community in North Belfast, just 35\% of respondents felt 'positive change' had occurred within policing. Similarly, Topping and Byrne (2012a) describe a 'relationship crisis' in some Catholic communities, with a consensus amongst local people that the PSNI was failing to adapt to peacetime demands. Conversely, some Protestant communities appear to be withdrawing from the PSNI, a police service 'changed' from the once Protestant-dominated Royal Ulster Constabulary (RUC) (Byrne \& Monaghan 2008). Trust in the police in NI thus appears to be socially and geographically variable, with variation within Protestant and Catholic populations being at least as important as variation between them.

\section{Figure 1 about here}

In this paper we draw upon data from a representative survey conducted in 2014, combined with Census and other local-area sources, to consider the individual and area-level correlates of trust in a society that remains deeply divided. Building on a body of literature that suggests neighbourhood context is an important factor shaping trust in the police, we explore whether trust in NI varies as a function of neighbourhood conditions, particularly ethnoreligious segregation and the potential interaction between religious identity and neighbourhood. To anticipate our main findings, deprivation (and class) in this context are strongly linked to trust, as is area-level ethnoreligious diversity. Yet, crucially, this latter finding seems consistent only among Catholics. Our results thus have implications for understanding the broader social conditions and interactions, beyond police activity, that shape public trust in this particular institution. 


\section{Trust in the police}

Trust can be conceptualised in various ways, but at its core it concerns our willingness "to rely upon, give control to, or otherwise 'be vulnerable to' ...institutions under conditions of risk" (PytlikZillig et al. 2015, p. 9). There is much evidence to suggest trust is premised on value congruence and shared group membership. In the context of policing, people's willingness to be vulnerable is anchored in identification with police and perceptions of common aims and shared means (Bradford et al. 2017, Hamm et al. 2017). Also important is a close association between the police, as representatives of order and cohesion, and the condition of local areas, i.e. the extent to which the police are perceived as representative of society, embodiments of commonly shared identities and of the 'general order' (c.f. Jackson et al. 2012; Thomassen and Kääriänen 2016). In the context of NI, the most pressing question concerns whether these ideas hold true when notions of locality, group identity and relations with the state are contested and/or in flux (Tankebe 2009). In a country that endured thirty years of internal armed conflict, and in which marked social division persists, what is the relationship between trust, identity and neighbourhood?

\section{Police reform and public trust in Northern Ireland}

In answering this question, history is the obvious starting point, in part because policing was "perhaps the single most emotive, divisive and controversial aspect" of the bitter conflict which NI suffered from 1968 to 1998 (Mulcahy 2006, p. 4, Hamill 2011, p. 18). Operationally and symbolically, the RUC was perceived by many Catholic communities as an oppressive force representing the coercive arm of an illegitimate British state. At the same time, it was perceived by most Protestants as a proud defender of Britishness in the face of a Republican terrorist campaign (Ellison 2010). The strong sense of 'ownership' by Protestants, coupled with heavy-handed policing tactics and extensive use of counter-terrorist powers, left many Catholic communities 'over-policed and under-protected' (Hillyard and Tomlinson 2000, Mulcahy 2006).

An extensive review of policing by the Independent Commission on Policing (ICP) was brokered as part of the country's 1998 peace agreement. A search for trust was at the core of the reforms, bolstered by a specific mandate to ensure "Northern Ireland had a police service that can enjoy widespread support from, and is seen as an integral part of, the community as a whole" (ICP 1999, p. 123). This was to be achieved by "policing with the community': the 175 reforms inspired by the ICP report sought to empower local communities to determine policing priories for their neighbourhoods, monitor police performance, and participate in community safety projects (Mulcahy 2008, Topping, 2008a, 2009)

This vision of policing as a collective community responsibility was to be brought about through the disbandment of the RUC and creation of the PSNI, intended to be a community-oriented service more representative of, and responsive to, groups across Northern Irish society (Topping 2008b, 2016). Communities received dedicated 'Neighbourhood Policing Teams', staffed by officers whose primary job to was foster and maintain connections in assigned localities. A 50:50 (Protestant - Catholic) recruitment policy was introduced, with the hope that a more representative organisation would appeal to alienated communities (Brogden 2001). Approximately one third of PSNI officers are now from a Catholic background, a figure significantly higher than was ever the case in the RUC (PSNI 2017), though still falling short of being representative of the population.

\section{The on-going challenges of establishing trust in a post-conflict society}

The new Northern Irish policing model has enjoyed international acclaim. Bayley (2008) labelled it as "the success story of the ... peace process", and Mulcahy $(2008$, p.129) describes how it has achieved a "near-mythic status as a place of pilgrimage for officials from around the world anxious to learn its lessons". However, as suggested by Ellison (2010), the "vigorous promotionalism" regarding the success of the police transformation process has, perhaps, been too quick to overlook formidable challenges that remain. Some of these relate to the workings of the new policing institutions and their willingness to embrace the ICP's vision of policing (Topping 2008a), while others linger from the seemingly intractable legacy of the conflict and engrained understandings of policing within NI's two main ethno-religious groups.

These community understandings are complex and varied. At the intra-communal level, there remain significant differences in attitudes towards, and affinity with, the new policing dispensation. Needless to say, there is no 'uniform' Protestant or Catholic 'view' of policing, with local politics, police practices and historical relations demarcating varied support or antipathy towards the PSNI from within Protestant or Catholic communities - either political or geographically defined (Byrne and Monaghan 2008; Ellison 2010). For some Protestants, historical affinity with the police has been challenged by the emergence of a less partisan service that is more politically neutral and representative. The PSNI has openly encouraged a positive relationship with Catholic communities and politicians long seen as the "enemy" (Topping 2015). Moreover the PSNI has taken a leading role in investigating deaths during the conflict and adopted a positive attitude towards public inquiries and inquests into state-related killings. Resistance to this investigatory work within unionism is linked to concern that the legacy of the RUC is being tarnished, with the bravery and sacrifice of its officers forgotten in an effort by Republicans to re-write the conflict (Lawther 2011). This reflects much broader unease within unionism over 
power-sharing, increased religious equality, and the visibility of an Irish culture some perceive as a threat to Protestant identity (Wilson 2016). Such sentiment has manifested itself in the form of disorder, most notably during the so-called 'flag protests' of 2012-13. The decision of Belfast City Council to reduce the number of days the Union flag flew at Belfast City Hall acted as a lightning rod for the expression of political discontent within Protestant /Unionist /Loyalist communities across the country (Nolan et al. 2014) and resulted in forty days of protests and public disorder (BBC 2013). By contrast, trust in the PSNI among many Catholic communities has grown, as witnessed in 2007 when Sinn Fein, the largest Nationalist/Republican political party, formally acknowledged and endorsed the PSNI. But in historically marginalised, primarily working class, Republican communities (once 'no go areas' for the RUC), the PSNI is still trying hard to win over 'hearts and minds' (Ellison et al. 2012, Topping and Byrne 2012a).

Police-community trust in both Protestant and Catholic areas has thus been strained Protestant/Unionists tend to believe the police have changed too much, while Catholics/Nationalists feel it has changed too little (Ellison et al. 2012, Mulcahy 2006, Topping 2008b). To establish greater trust, the PSNI have invested heavily in everyday police-community interactions:

"We call these encounters 'moments of truth'. They're the moments when you [the public] see whether we are delivering on our commitments and judge us accordingly. There are more than half a million of these moments of truth in Northern Ireland every year." (PSNI, 2011, n.p)

For traditionally marginalised groups, procedural fairness during such interactions can be especially important, with people from such groups sensitive to signs of respect and inclusion from the police as representatives of dominant yet valued social categories from which they have been excluded (Gau and Brunson 2010, Huq et al. 2011). In the most alienated communities, however, police-community interactions are heavily mediated, even negated, by the historical 'baggage' of the conflict, as well as local disputes over the policing of contentious parades and protests, or paramilitary activity (Byrne and Monaghan 2008, Byrne et al. 2014). Particularly problematic is the claim that police are 'prototypical group representatives' (Sunshine and Tyler 2003) with whom people wish to identify and from whom they seek identity-relevant information. Among Republican communities, identity has been, and in many cases still is, shaped by opposition to the police. As one young person in McAlister et al's (2009, p. 76) study commented: “...these people in politics they tell ye 'Aw, trust the police - they do this, they do that'. But it's like strangers comin' into your areas and invadin' your space”.

\section{Neighbourhood context and trust}

The PSNI continues to face ongoing challenges in establishing trust among elements of both main communities. But an institutional frame that focuses on the activity of police can lose sight of the wider social, cultural, political and economic processes that shape public trust. Of particular importance is the condition of people's neighbourhoods and how they interpret and understand these conditions (Brown and Benedict 2002, Bradford and Myhill 2015). With a few exceptions (Ellison et al. 2012, Tankebe 2009), the weight of evidence suggests that ideas about the police, and experiences of policing, are linked to perceptions of neighbourhood and community (e.g. Cao et al. 1996, Sampson and Bartusch 1998; Jackson and Bradford 2009; Kwak and McNeeley 2017). People who live in less disorderly and more socially cohesive and efficacious neighbourhoods tend to express significantly higher levels of trust in the police, at least in the London context (Jackson et al. 2012).

Explanations for the link between trust and social characteristics of the neighbourhood (e.g. collective efficacy) rely, in large part, on the idea that police symbolically embody order and the effort to reproduce it. When 'community' seems cohesive, and social control processes correctly oriented and effective, trust is higher (on average). It follows that wider processes of social ordering such as economic development or decay - which may in reality be very distant from actual police activity - become important factors shaping public attitudes (Loader and Mulcahy 2003). As Sampson (2012) notes, one of the most important features of economic decline in local areas is the damage done to social cohesion and collective efficacy - and therefore trust.

Such ideas have found widespread application, particularly in the fractured and contested landscape of US policing. Kirk and Papachristos (2011), for example, argue that legal cynicism - as a particular cultural frame and a way of relating to legal authorities - is generated in part when "people come to understand that the dominant societal institutions (of which the police and the justice system are emblematic) ... offer them little in the way of security, either economic or personal" (2011, p. 1198). People's relations with the police are damaged when processes of social ordering seem, and are, ineffective, malfunctioning and even predatory - a claim that relies in part on the idea that police represent the effort to produce and maintain normative social order, as well as more proximate factors, most notably the aggressive styles of policing experienced by many living in deprived areas (Kirk and Matsuda 2011).

Policing in NI might be considered to pose a particular challenge to such ideas, since the affective link between 'police', 'community' and 'order' is fragile and disputed on political, cultural, and operational grounds. Paramilitaries previously played a prominent social control role in some neighbourhoods, while what constitutes 
'dominant societal institutions' might vary with community identity. Under such conditions, neighbourhood level social control processes may be unimportant in terms of trust formation because their success or otherwise is not associated, in people's minds, with the police (Topping and Byrne 2012a). Yet, the very formation of the PSNI is premised on the idea that it does represent - embody the values of, share priorities with, and belong to - all communities in NI. Whether this claim is accepted by large sections of the population remains debatable, but its very existence, and the changes heralded by the reform process, suggests the possibility that even among previously alienated communities and groups, the PSNI has come to represent the general social order (as opposed to particular, sectional visions). If this is the case, then in NI, as elsewhere, neighbourhood conditions may be important predictors of public trust in the police.

Moreover, irrespective of any affective links between police and 'community', in almost any context the former can represent the 'fight against crime' and garner public trust when crime seems under control (Jackson and Bradford 2009). Although instrumental concerns about crime and risk may be distinguished from "thick" (and overlapping) normative issues of identity and community, police performance might represent a "thinner", but nonetheless important, notion of morality (Bottoms and Tankebe 2012). In some of NI's communities, where a 'base-line' of effectiveness in fighting crime may yet to be achieved, and where swift summary justice administered by paramilitaries was once the norm, apparent success in dealing with crime might be an important factor generating trust in police, not least because a (relative) absence of crime may suggest police are 'doing the right thing'.

\section{Diversity and trust}

A further complicating factor is the ethno-religious segregation that characterises Northern Irish society. While wider issues of community diversity (such as race and gender) may also be in play in NI (Clements, 2008), the question of ethno-religious identity still determines contemporary debates around policing, and we limit our attention in the current paper to this specific form of 'diversity' and its implications. Ethno-religious division is still a prominent feature of life in Northern Ireland. The number of interface walls separating Loyalist and Republican areas have increased from 22 to over 100 since the implementation of the Good Friday Agreement in $1998,90 \%$ of social housing is still segregated on religious grounds, and $94 \%$ of children attend non-integrated schools (Campbell 2017, Merrilees et al. 2017). Any account of the association between neighbourhood conditions and trust in police in this context must take account of this segregation.

We draw here on Allport's 'contact hypothesis' (Allport 1954, Dovidio et al. 2003) to suggest that community contact may be an important factor shaping trust in the police (c.f. Cairns \& Darby 1998 Shirlow and Murtagh 2006). According to the intergroup contact paradigm, people who have more contact with outgroup members are more likely to trust those outgroups and to shift group boundaries such that they are crossed more often and/or become less salient. This general process might affect trust in the police in one (or both) of two ways. First, those who live in less segregated areas may, to the extent this implies more contact with outgroup members, be more inclined to trust others and to expand their boundaries to include those others as 'us', thus enhancing social cohesion at subjective and possibly objective levels (Pettigrew and Tropp 2006, Tam et al. 2009, Christ et al. 2014). Because social cohesion is linked to trust in police, social diversity in a society such as NI might in a general sense exert a positive influence on such trust.

Second, and in contrast, some communities in NI may still associate the PSNI with sectional interests and thus particular outgroups - most obviously, sections of the Catholic/Nationalist community may associate the PSNI with the 'old' RUC/Protestant regime (Byrne and Monaghan 2008). It may be, therefore, that it is among Catholics in particular that increased contact with outgroup members (i.e. Protestants) will enhance trust in the PSNI, which remains a predominantly Protestant organisation (70\% Protestant, 30\% Catholic, PSNI 2017). Catholic members of more diverse communities may be more inclined to trust the police even if they continue to conceive of the PSNI as 'other', because increased intergroup contact promotes more positive views of the outgroup. It should also be noted that this process is premised on a general association between police and Protestantism/Unionism; many off-duty police officers in NI remain reluctant to disclose their occupation to strangers (Topping 2015), dampening the potential for intergroup at the individual level to influence trust.

\section{Hypotheses}

Distilling the discussion above, two primary hypotheses guide our analysis. H1 is that individuals who live in areas of greater ethno-religious diversity will be more likely to trust the PSNI because they are more likely to have contact with outgroup members, thus enhancing (subjective) social cohesion. But despite its efforts, the PSNI may still be associated with sectional (i.e. Protestant/Unionist) interests, at least within some Catholic communities. $\mathbf{H} 2$ is therefore that any such effect will be particularly strong among Catholics, because with greater diversity comes greater contact with others - largely Protestants - who are perceived to share group membership with the PSNI. These hypotheses are therefore potentially although not necessarily in conflict with one another.

We also explore some additional hypotheses drawn from the existing literature. These revolve around the idea that when local order is seen to be stable, strong and successful in protecting the interest of residents, the 
police, representative of that order, garner trust: $\mathbf{H 3}$ is that trust will be higher in less deprived neighbourhoods; H4 is that trust will be higher when crime is lower; H5 is that trust will be low when low-level disorder is high; and $\mathbf{H 6}$ is that trust will be low when collective efficacy is low. Addressing these hypotheses will allow us to make inferences about how (dis)similar the foundations of public perceptions of police are in NI compared with elsewhere.

\section{Data and Methods}

The survey data for this paper was provided by the NIPB. The data are based upon 1009 face-to-face interviews conducted in February 2014. ${ }^{1}$ Stratified random sampling was used to select sampling points, after which a quota sampling methodology was used, with quotas for age, gender, religion, region and social class. Surveyors used electronic hand-held devices to collect data, and the survey work, conducted by a commercial company, was undertaken in compliance with international standard ISO 20252:2012. ${ }^{2}$ In the dataset provided some 914 respondents had full postcode data and could be assigned to an Super Output Area (SOA) $)^{3}$ - only these individuals are included in the analysis presented below ${ }^{4}$. SOAs are an area classification used in the UK Census and there are 890 SOAs in NI, with an average population of just over 2,000 people (and just less than 800 households). Respondents lived in 221 SOAs, with an average of 4.1 respondents per SOA, so given this 'clustered' data structure, we used multi-level regression modelling to explore our hypotheses (discussed below).

\section{Response variables}

In common with other recent studies of police-community relations (Stoutland, 2001; Hohl et al. 2010), we consider trust to be a multi-dimensional construct. Specifically, we propose that although trust is crystalised in a willingness to be vulnerable, it is founded on perceptions of (judgements about) competence and good intentions. While we do not have available measures of willed vulnerability (e.g. Hamm et al. 2017), we do have measures of perceptions of intentions and competence, and we distinguish between trust in police fairness and community engagement, on the one hand, and trust in police effectiveness on the other (c.f. Bradford et al. 2009). The label 'trust' is appended to each construct as a reminder that beliefs about, for example, the fairness of the police constitute trust, since one is more likely to be accept vulnerability if one believes police officers behave in a fair manner, and reflect trust, since a positive answer to survey items such as "the police in your area would treat you with respect if you encountered them for any reason" must, because the respondent cannot truly 'know' the answer to such a question, reflect an element of faith. which Giddens (1991) insists is a key aspect of trust.

All survey items used Likert-type response scales (fairness and community engagement had 5-point scales, effectiveness items had 7-point scales). Latent variable modelling (using the statistical package Mplus 7.2) allowed us to derive and validate the two measures of trust, along with a measure of perceived disorder (see below). Full Information Maximum Likelihood estimation was used, meaning that cases with some missing data were not dropped from the analysis (with the result that all 914 'post-coded' individuals were included in subsequent analysis). A three factor model with no cross- loadings fitted the data well. We therefore proceed with the two components of trust as our response variables (see Appendix Table 1 for item wordings, factor loadings, and fit statistics). All latent variables were scored such that 'high' values equalled more trust. Note that trust in police fairness and trust in police community engagement can be considered separate constructs, and indeed a four-factor model that treated them as such fitted the data equally well, but the fairness and community engagement measures were very highly correlated $(r=>.9)$, so for the sake of parsimony we proceed with the two-factor model of trust. In sum, it appears that respondents to the survey drew very little distinction between how fair they thought the police 3 were, and how engaged with their community they were through police, so it seems justifiable to combine the sentiments into one index.

\section{Explanatory variables}

\footnotetext{
${ }^{1}$ This survey has been fielded in other years, but among the datasets available to us, only the 2014 survey contained items on perceived disorder, a key predictor of trust, so we limit analysis to this year only.

2 The authors were provided with the raw survey data by the Northern Ireland Policing Board. More detail on the commercial survey can be found at: https://www.nipolicingboard.org.uk/sites/nipb/files/media-files/What-influences-people's-perceptionabout-whether-the-police-are-doing-a-good-job-in-NI-february-2014.pdf (last accessed April 2018)

3 The Northern Irish SOA is different from the equivalent unit in England and Wales, and is not disaggregated into LSOA or MSOA

${ }^{4}$ The excluded individuals did not differ significantly from those included across any of the individual level variables included in our models
} 
A range of explanatory variables were needed to assess our hypotheses. First, and as noted, a measure of respondent-assessed neighbourhood disorder was generated to address H5. It should be noted that this is not a measure of the actual level of 'disorder' in a respondent's local area but rather their assessment of the extent to which low-level disorder was a 'problem'. Observed indicators utilised 4-point Likert-type scales, and the latent variable was scored such that high equalled more perceived disorder.

Data from the 2011 Census were used to address H1 and H2. We derived a measure of ethno-religious diversity at the SOA level in order to do so. Hirschman's concentration index (1964) can be interpreted as the probability that two randomly selected individuals from the same area will be from different groups (c.f. Sturgis et al. 2014, p. 7-8). Three groups were used to create this measure for the current context. These groups were derived from the religion question in the NI version of the Census: Protestants; Catholics; and 'Other'. The last category covers a wide range of individuals, including those who refused to answer the question, identified as non-believers, belonged to non-mainstream Christian denominations (e.g. Evangelicals), or belonged to a nonChristian religion. The inclusion of this residual category in our measure of diversity is justified on the basis that in NI to indicate oneself as neither (a) mainstream Protestant nor (b) Catholic is, in itself, to make a statement about one's politics and therefore, in this context, identity (as someone who has not 'taken sides' in the conflict and post-conflict situation). Within our dataset, the derived scale had a mean of .5, SD of .13, a minimum of .16 and a maximum of .66. A measure of the survey respondent's own religion was entered into analysis as a set of dummy variables representing the same three groups: Protestants (43 per cent of respondents); Catholics (39 per cent); and 'other' (18 per cent).

Census data was also used to address H3. A measure of concentrated disadvantage at the SOA level was generated from the following Census items: proportion of households with no one in employment and dependent children; proportion of households with at least one person with long term health problems and/or disability (with and without dependent children); proportion lone parent households with dependent children; proportion of households living in socially rented accommodation; and the proportion of unemployed individuals. All these measures loaded very strongly onto one underlying factor, which was extracted and saved for analysis. Due to a heavy skew this measure was log transformed, after addition of a constant. The resulting scale had the following characteristics: Mean $=2.29 ; \mathrm{SD}=.10 ; \mathrm{Min}=2.17$; $\mathrm{Max}=2.69$. Higher scores on this scale indicate more (concentrated) disadvantage.

Data from the 2010 Northern Ireland Multiple Deprivation Measure (NIMDM) was used, derived from the Northern Ireland Statistics and Research Agency (NISRA 2010) were used to address H4. The 'crime and disorder' domain is based on 5 measures, the 2004/5 - 2008/9 rates of: violent, robbery and public order crimes; burglary; vehicle theft; criminal damage; deliberate primary and secondary fires; and anti-social behaviour incidents (2006/7 - 2008/9). Ideally this measure would have been disaggregated into distinct indices of 'crime' and 'disorder' (to provide an 'objective' measure of disorder to complement the 'subjective' measure described above), but they were so highly correlated $(\mathrm{r}=.85)$ as to likely cause problems with multicollinearity in our models. The combined score was therefore used, and was entered as a rank, i.e., across all SOAs in NI, that with the highest level of crime and disorder was assigned a value of 1 , that with the next highest a value of 2 , and so on. The ranks of the SOAs within the dataset ranged from 1 to 886 .

Finally, data from NISRA was used to create a measure of neighbourhood collective efficacy. This is a complex concept that combines "social cohesion (the "collectivity" part of the concept) and shared expectations for control (the "efficacy part of the concept") (Sampson, 2012: 152, emphasis in original) with institutional context, i.e. the resources and mechanisms in place that residents can draw upon and work with when engaging in social control activity (ibid.). Due to a lack of data in the NIPB survey, we use administrative data to focus only on this latter aspect of collective efficacy. In 2008, the NI Community and Voluntary Association sent out a survey to 6,293 community and voluntary groups and housing associations ( $26 \%$ responded). These returns were aggregated to the SOA level, enabling us to produce an estimate of the number of community organizations per 1,000 population and thus a measure of 'institutional density' at the local level. The original variable was heavily skewed (a few areas had a much higher concentration of community organizations than everywhere else). The natural $\log$ was taken, after addition of a constant, resulting in a scale with Mean =1.07; SD = .54; Min =0; Max $=4$. Similar measures have been used in prior studies, e.g. Kawalrerowicz and Biggs (2015) used a measure of the neighbourhood density of charitable organisations as an indicator of social (dis)organization, while Sampson's (2012, p. 197) measure of the density of non-profit organisations is considered an indicator of "collective civic action".

\section{Control variables}

Two important control variables were included in the analysis to represent i) community tension and ii) police activity. The former may be important in shaping trust in the police in NI, albeit in what are likely to be complicated ways. We used data from the Parades Commission for Northern Ireland (PCNI) online database to create a variable indicating whether the respondent lived near the route of a 'contentious parade' (a parade considered to have "the potential to raise concerns and community tensions", PCNI 2016). Such parades occur at 
well-known 'trouble spots', where community tensions are already high. These are usually interface areas, where Republican and Loyalist communities share tight urban boundaries (Jarman 2006). Any instances of a 'contentious parades' that took place in the respondent's, or an immediately adjoining, SOA in the year preceding the survey was recorded and used to create a dummy variable, coded 1 if such a parade occurred and 0 if it did not. While this is an imperfect measure, it does take some account of the extent to which the location of contentious parades in particular areas both reflect and reproduce underlying, on-going community tensions.

Contact with the police is an important factor shaping public trust. Unfortunately, the NIPB data did not include variables capturing such contact, and this is an important limitation of our study. We did however obtain data from PSNI's community prioritisation index (CPI), which is a composite index intended to allow "the identification and prioritisation of areas based on the experience of community harm and the potential risk from vulnerability and disengagement" (PSNI 2011). The index is built up from measures of crime, disorder, community tension and deprivation, among others, and aggregated at the SOA level. Relevant for our purposes, though, is not how the CPI was produced (or that it is comprised partly of measures we have included separately in our models) but that it is used to guide PSNI resources to areas of concern (CJINI 2016, NIPB 2016a). We therefore include it in our analysis as a proxy measure for PSNI activity at the local level, on the assumption that higher levels of police activity are correlated with higher levels of police contact among residents. We also controlled for a range of socio-demographic factors - age, gender, employment status and social class - and the population density of the SOA (according to the 2011 Census).

A further limitation of this study is that many of the area level variables relate to data collected some years before the survey took place. However, the characteristics of local areas, particularly those relating to crime, deprivation and social cohesion, have been shown to be remarkably stable over time. As Weisburd et al. (2012, p. 10) note, "crime is strongly concentrated at places, and such concentration are stable over long periods". Similarly, Sampson and Morenoff (2006) report a strong correlation ( $>$.85) between neighbourhood poverty rates in Chicago in 1970 and in 1990; and Sampson (2012, p. 197) reports a similarly high correlation between the neighbourhood density of non-profit organisations in 1990 and in 2005 . In short, there is much to suggest that relevant characteristics of local areas are stable over time. Using area level data derived some years before the survey data were collected should not therefore excessively bias our results.

Finally, we note that while our hypotheses (particularly H1 and H2) indicate causal processes, our 'snap shot' data cannot assess these, meaning that any evidence in support of the hypotheses is purely indicative, and, we hope, to be taken merely as an invitation for future research using more apposite data.

\section{Results}

\section{Bivariate analysis}

Table 1 shows the bivariate correlations between our key measures. Note that there is a positive correlation between diversity and trust (people who lived in more diverse areas tended to trust the police more) that is roughly equal in size to the negative correlation between disadvantage and trust (people who lived in more disadvantaged areas tended to trust the police less). As in many other studies, we find a negative correlation between perceived disorder and trust; unlike other studies, though, there appears to be little if any pairwise correlation between institutional density and trust in the police. Note also (a) the negative, albeit weak, correlations between diversity and disadvantage and crime/disorder (more diverse areas tended to be somewhat less disadvantaged) and (b) that institutional density tended be higher in areas with more crime/disorder and with higher levels of disadvantage, suggesting that community organisations tended to be clustered in more deprived areas.

\section{Table 1 near here}

\section{Multivariate analysis}

Turning to multivariate analysis, Table 2 shows results from a series of multi-level linear regression models predicting trust in police fairness and community engagement. We first fitted an empty 'variance components' model, not shown in table, which shows how much variation in the response variable is explained at level 2 (i.e. at the SOA level). This model returned a value of .14 for the Intra Class Correlation (ICC), which is in the current context quite large (c.f. Jackson et al. 2012). Around one seventh of the variation in this component of trust was explained at the area, rather than the individual, level.

Model 1 includes only area level correlates. Of these potential predictors, only ethno-religious diversity, concentrated disadvantage and population density are statistically significant at the conventional .05 level. Trust in the police in NI is lower in more deprived areas. Conditioning on the other variables in the model, moving from the least to the most deprived area was associated with a .7 unit decrease in trust (on an overall scale length of 4). Yet, we also find that as diversity increases, so does the expected value of trust in the police. All else being equal, moving from the least to the most diverse SOA was associated with a .4 unit increase in trust, i.e. around 10 per cent of the range of the trust scale. Finally, all else equal trust tends to be slightly higher in more densely populated 
(i.e. urban) areas. It may be easier, for a range of practical reasons, for police to 'engage' with communities in more built up areas (Bradford and Myhill, 2015, report that trust in the police may be lower in rural areas of England and Wales, too).

\section{Table 2 near here}

Model 2 in Table 2 adds individual level correlates. As in many other studies, we find that people who perceive more disorder around them tend to trust police less, and that older people trust somewhat more than younger people. There is also some evidence of higher levels of trust among women and those from social class ABC1 (upper/middle class and lower middle class) and lower levels among the unemployed and 'homekeepers'/retired individuals. Strikingly, there is no evidence for ethno-religious variation in trust. Controlling for the other variables in the model, Catholics were no more or less likely to trust police than Protestants. Most importantly, though, the coefficient for ethno-religious diversity retains significance in this model, albeit at the 10 per cent level $(\mathrm{p}=.06)$. Even controlling for area- and individual-level correlates, people who lived in more diverse areas tended to trust police more.

Finally, Model 3 tests H2: the idea that diversity is more, or indeed only, important for Catholics. Here we find that the Catholic*diversity interaction term is statistically significant $(\mathrm{p}=.051)$, positive, and substantively large $(\beta=1.23)$, while the main effect for diversity shrinks in size and loses statistical significance. This suggests that increasing diversity is important for trust in the police, but only among Catholics. The full implication of this interaction is shown in Figure 2, which shows predicted values for trust generated from Model 4. Moving from less to more diverse areas, trust in police fairness and engagement rises substantially among Catholics; while it falls among Protestants, this effect is not statistically significant at any conventional level. Note also that in Catholics living in less diverse areas tend to trust the police significantly less than Protestants living in similarly non- diverse areas.

\section{Figure 1 near here}

Turning to the second component of trust, police effectiveness, Table 3 shows results from a further series of models, specified as before. Some 13 per cent of the variation in trust in effectiveness is explained at the SOA level (variance components model not shown). Model 1 shows that concentrated disadvantage is again a strong predictor of trust (conditioning on the other variables in the model, moving from the least to the most deprived area was associated with a .8 unit decrease in trust). The population density coefficient is also significant in this model, and all else being equal, trust in police effectiveness again tends to be slightly higher in more densely populated (i.e. urban) areas. Finally, conditional on the other area level correlates, there is no significant association between diversity and trust - the pairwise correlation shown in Table 1 appears to be accounted for by other factors.

Table 3 near here

As before, people who perceive more disorder around them trust police less, as do younger people, the unemployed and those from social classes C2DE (skilled working class / other working class / long term dependent on the state due to sickness, unemployment, pensioners), although gender is not a statistically significant predictor of this measure of trust (Model 2).

Finally, Model 3 in Table 3 adds the religion/diversity interaction. Here, the Catholic*diversity interaction term is positive and at statistically significant at the conventional level $(\mathrm{p}=.03)$. Given that the main effects for Protestant and diversity are not statistically significant in this model we can again conclude that increasing diversity is likely to be important for trust, but only among Catholics. Figure 3 shows fitted values to illustrate this. Moving from less to more diverse areas, trust in police community engagement rises substantially among Catholics (note again the decline among Protestants, although this latter statistical effect is not significant at conventional levels).

\section{Figure 2 near here}

\section{Additional analysis}

In light of the findings presented above, we conducted some additional analyses. First, there is much to suggest that social class plays a significant role in NI, and that the intersection of religion and class may be an important factor shaping relations with the police (e.g. Ellison et al. 2012, Nolan 2014). Accordingly, we tested for interactions between (a) religion and social class at the individual level and (b) religion at the individual level and deprivation at the area level. None of the interactions were significant ( $p>.1$ in every case). Class is an important predictor of trust in the police in NI (note the sign, significance and relative size of the main effects of social class 
and area level deprivation in the models shown above), but this association is largely invariant across the two main groups.

Second, we re-estimated all models, but this time substituting the diversity measure with the proportion of Protestants living in each SOA. Results (available from the lead author) were similar to those shown in the models: Catholics living in areas with low proportions of Protestant residents trusted the police significantly less than Catholics living in areas with higher proportions of Protestant residents. Conversely trust among Protestants did not vary significantly by the proportion of Protestant residents.

Third, while most of our results are consistent with extant research, one divergent finding is the relationship between institutional density (as an aspect of collective efficacy) and trust in the police. Whereas other studies have found a positive association between trust and social cohesion and/or collective efficacy, at an individual (e.g. Bradford and Myhill 2015) and area level (e.g. Jackson et al. 2012), we found little correlation between the concentration of community organisations and trust. One explanation for this relates to the nature of community organisations in NI. Their prominent role in communities has long been recognised (Brogden 1998, McEvoy et al. 2002). Many were formed as part of civil society movements during the conflict, when their role was to provide community support outside the remit of the state. Approximately $75 \%$ of these voluntary and community groups belong mainly or wholly to either Protestant or Catholic communities, reflecting strong sectarian division (Topping and Byrne 2016). Groups based in Catholic areas, for example, are traditionally "characterised by activism against, or [as working] in parallel to the state, underpinning ... heightened collectivist attitudes" (Topping, 2009, p. 116). In as much as institutional density is linked to collective efficacy, the latter may exist here in a form that further entrenches the effects of ethno-religious segregation, therefore inhibiting trust in police by promoting inward looking forms of social cohesion.

To explore this idea, we tested the interaction between institutional density and diversity as a predictor of the trust measures. The interaction effect was significant in both cases - the results from the fairness/engagement model are summarised in Figure 3 (the effectiveness model produced almost identical results). Holding constant all other predictors, there was a negative association between institutional density and trust when diversity was low, but a positive association between institutional density and trust when diversity was high. High institutional density in segregated areas may indeed imply an inward-looking cohesion, based on bonding social capital, which strengthens ingroup/outgroup divisions and thus undermines trust in the police. But when diversity is higher, greater institutional density may imply more outward facing forms of social cohesion, and bridging social capital (because for example there are more forums for people to meet others), thus enhancing trust in the police. It may also be that in more diverse areas people tend to draw an association between a strong institutional framework and the police, but in less diverse areas institutional frameworks are associated with sectional interests, possibly defined against the police or the collective identity police represent. We note, however, that while these findings are suggestive, they are purely indicative, not least because we only have a partial measure of the underlying concept of collective efficacy available - it may be that a fuller measure would have produced different outcomes.

\section{Figure 3 near here}

\section{Discussion}

Returning to our research hypotheses, we found initial support for $\mathrm{H} 1$, in that individuals who live in areas of greater ethno-religious diversity in NI exhibit more trust in the police - yet our results demonstrate that this pattern only really holds only among Catholics (H2). It may well be that the PSNI remains associated with the Protestant community, at least among significant numbers of Catholics, such that it is only among the latter that living in a more diverse area promotes trust via increased intergroup contact. H3 was also supported by our data, in that trust was higher in less deprived neighbourhoods, as was H4, with people who perceived more disorder around them also tending to express less trust in police. Our remaining hypotheses were not supported. Trust was not higher when crime (and disorder) was lower (H4); and neighbourhood collective efficacy was not in a general manner associated with trust (H6) - but this was because dense community networks were a negative predictor of trust when diversity was low and a positive predictor when diversity was high (these divergent effects cancelling each other out in models that did not include the interaction term).

Taken together, these findings suggest police-public relations in NI are in many respects remarkably normal. The idea that disadvantage and disorder are strong predictors of trust in the police is reinforced by our data. In NI, as elsewhere, a disorderly and impoverished social environment signals the failure of the police to maintain order. It therefore seems the PSNI may indeed represent the (collective) effort to maintain social order across the different communities. These findings serve as a contrast to the ongoing 'extremities' of the postconflict environment in NI (Seymour 2017, Topping and Byrne 2012b).

Yet, we have shown that the local context is, of course, important. Our core finding is that Catholics living in areas of greater ethno-religious diversity have more trust in the PSNI. It may well be that greater exposure to Protestant and other outgroups may translate into a greater sense of affinity with the PSNI, which remains 
predominantly associated with the Protestant outgroup. The segregated nature of Northern Irish society therefore influences public trust in the police not through a simple Catholic/Protestant dichotomy, but via the interplay between identity and place (Shirlow and Murtagh 2006, Wilson 2016). It seems that it is segregation, rather than individual level religion, that is the important factor, albeit that further research will be required to tease out the likely complex web of associations.

Such research would also need to attend to the views of Protestants. Trust in police does not appear to vary with diversity among the latter. Does this indicate that among Protestants the PSNI still represents 'us'? Perhaps not, given that Protestant community experiences of PSNI are tempered with a sense of 'loss' arising from the disbandment of the RUC in 2001 and various tensions between police and (mainly) socio- economically deprived Protestant communities (Byrne \& Monaghan 2008). The general, albeit non-significant, pattern that trust was lower among Protestants in more diverse areas (see Figures 1 and 2) is suggestive. The lack of statistical significance could in part be due simply to relatively small numbers of Protestants sampled in each area. If this is the case, it may be that for Protestants, a great proportion of Catholic residents in a locality is viewed as a 'threat', with this insecurity reflected in (more negative) attitudes towards PSNI. Again, more work is needed to properly investigate this. Future research would also need to attend to the quantity and quality of intergroup contact, rather than simply assume that greater diversity leads to more ('good') contact. More sensitive survey instruments than those currently available will be needed to address these kinds of questions. Finally, with regard to young people as a 'post-conflict generation', further analysis could consider more closely the attitudes and behaviours of those without direct experience of the RUC (Leonard and McKnight 2014, 2015, Taylor et al. 2017).

\section{Conclusion}

Existing national survey-based research on public trust in the PSNI, though helpful in exploring general trends, has rightly been noted as "less useful in highlighting police-community relations in specific neighbourhoods and amongst specific social groups" (Ellison et al. 2012, p. 252). In this study we have combined a nationally representative sample with close attention to the local dynamics of trust to explore the interplay between ethnoreligious identity at the individual and area-level characteristics. While a substantial body of work exists on public trust in police, this is one of the first studies to consider the impact of community diversity, and one of the few to consider trust in ethnically divided societies (outside the United States, at least; Hasisi and Weitzer, 2007). The analysis presented here represents a significant step forward in developing understandings of public trust within socio-politically complex, segregated, policing environments.

The wider implication of our findings is that segregation, sectarianism and societal division may shape public trust in the police in ways that escape the best funded reform process in the world (Bayley 2008). This, in turn, raises new questions for policing in segregated societies more generally, especially how police practice can be re-oriented to overcome culturally, socially and politically embedded barriers to trust, as opposed to reform processes that concentrate on altering the structure and practice of police organisations. With policing always seen as the final piece of the political 'jigsaw' in NI, a feeling has persisted that if policing could be 'gotten right', the other pieces of the wider peace process would fall into place (O'Rawe 2003). Yet, in spite of far-reaching community engagement and oversight mechanisms, policing has not been fully 'gotten right'. The conclusion of our findings is that the glacial speed of societal change, integration and understanding of the conflict in NI provides a significant barrier to the establishment of trust in the police amongst some of the country's most marginalised and segregated communities - where, of course, it is needed the most. 


\section{References}

Allport, G.W., 1954. The nature of prejudice. Reading, MA: Addison-Wesley.

Bayley, D. H., 2008. Post-conflict police reform: is Northern Ireland a model? Policing, 2(2), 233-40.

BBC NI, 2013. Union flag protest cost police over $£ 7 \mathrm{~m}, 8^{\text {th }}$ January. Available from: http://www.bbc.co.uk/news/uk-northern-ireland-20943293 [accessed 6 April 2018].

Bottoms, A. and Tankebe, J., 2012. Beyond procedural justice: A dialogic approach to legitimacy in criminal justice, The journal of criminal law and criminology, 102(1), 119-170.

Bradford, B. Jackson, J., and Stanko, E.A., 2009. Contact and confidence: Revisiting the impact of public encounters with the police, Policing and society 19, 20-46.

Bradford, B. and Myhill, A., 2015. Triggers of change to public confidence in the police and criminal justice system: Findings from the crime survey for England and Wales panel experiment, Criminology and criminal justice, 15(1), 23-43.

Bradford, B. Jackson, J., and Hough, M., 2017. Trust in Justice, in E. Uslaner, ed. The Oxford Handbook of Social and Political Trust. Oxford: Oxford University Press.

Brogden, M., 1998. Two-tiered policing - A middle way for Northern Ireland. Available from: www.cain.ulst.ac.uk/issues/police/docs/demdial.htm [accessed 24 July 2017]

Brogden, M., 2001. The Patten report: A unitary solution to a multi-dimensional problem, Policing and society, $11,273-295$.

Brown, B. and Benedict, W.R., 2002. Perceptions of the police: Past findings, methodological issues, conceptual issues and policy implications, Policing: An international journal of police strategies \& management, 25, 543580.

Byrne, J. and Monaghan, L., 2008. Policing loyalist and republican communities: Understanding key issues for local communities and the PSNI. Belfast: Institute for Conflict Research.

Byrne, J. Topping, J. R. and Martin, R,. 2014. Northern Ireland Policing Board confidence in policing research: Key drivers of confidence. Belfast: Northern Ireland Policing Board

Cairns, E. and Darby, J., 1998. The conflict in Northern Ireland: Causes, consequences, and controls, American Psychologist, 54, 754-760.

Cao, L. Frank, J. and Cullen, F.T., 1996. Race, community context and confidence in the police, American journal of police, 15(1), 3-22.

Campbell, C., 2017. Flaws exposed in plans to remove Northern Ireland's peace walls', The Detail TV $22^{\text {nd }}$ May, Available from: http://www.thedetail.tv/articles/government-revise-down-interface-removal- target [accessed 24 July 2017].

Christ, O. Schmid, K., Lolliot, S., Swart, H., Stolle, D., Tausch, N., Ramiah, A., Wagner, U., Vertovec, S. and Hewstone, M., 2014. Contextual effect of positive intergroup contact on outgroup prejudice, PNAS, 111(11), 3996-4000.

Clements, P., 2008. Policing diversity. Oxford: Oxford University Press.

Criminal Justice Inspection Northern Ireland [CJINI], 2016. Anti-social behaviour a follow up review. Belfast: CJINI. Available from: 
http://www.cjini.org/getattachment/c5dfad32-6e77-4bac-af99-90849719270e/Anti-Social- Behaviour.aspx [Accessed 2 February 2017]

Dovidio, J.F. Gaertner, S.L. and Kawakami, K., 2003. Intergroup contact: The past, the present and the future, Group processes and intergroup relations, 6(1), 5-21.

Ellison, G., 2000. Reflecting all shades of opinion: Public attitudinal surveys and the construction of police legitimacy in Northern Ireland, British journal of criminology, 40, 88- 111.

Ellison, G., 2010. Police-community relations in Northern Ireland in the post-Patten era: Towards and ecological analysis, in J. Doyle (ed.). Policing the narrow ground: Lessons from the transformation of policing in Northern Ireland. Dublin: Royal Irish Academy, 242-276

Ellison, G. Pino, N. and Shirlow, P., 2012. Assessing the determinants of public confidence in the police: A case study of a post-conflict community in Northern Ireland, Criminology and criminal justice, 13(5), 552-576.

Gau, J. and Brunson, R., 2010. Procedural justice and order maintenance policing: A study of inner-city young men's perceptions of police legitimacy, Justice quarterly, 27(2), 255-279.

Giddens, A., 1991. Modernity and self-identity. Cambridge: Polity Press.

Hamill, H., 2011. The hoods: Crime and punishment in Belfast. Oxford: Princeton University Press.

Hamm, J. A. Trinkner, R. and Carr, J. D., 2017. Fair process, trust, and cooperation: Moving toward an integrated framework of police legitimacy, Criminal justice and behaviour, 44(9), 1183-1212.

Hasisi, B. and Weitzer, R., 2007. Police relations with Arabs and Jews in Israel, British journal of criminology, 47, 728-745.

Hillyard, P. and Tomlinson, M., 2000. Patterns of policing and policing Patten, Journal of law and society, 27(3), 394-415.

Hirschman, A.O., 1964. The paternity of an index, The American economic review, 54(5), 761-762.

Hohl, K., Bradford, B., \& Stanko, E. A. 2010. Influencing trust and confidence in the London Metropolitan Police: Results from an experiment testing the effect of leaflet drops on public opinion, British journal of Criminology, 50(3), 491-513.

Huq, A., Tyler, T. and Schulhofer, S., 2011. Why does the public cooperate with law enforcement? The influence of the purposes and targets of policing, Psychology, public policy and law, 17(3), 419-450.

Independent Commission on Policing in Northern Ireland (ICP) 1999. A new beginning: Policing in Northern Ireland - The report of the Independent Commission on Policing in Northern Ireland [Patten Report]. Belfast: Independent Commission on Policing in Northern Ireland.

Jackson, J. and Bradford, B., 2009. Crime, policing and social order: On the expressive nature of public confidence in policing, British journal of sociology, 60(3), 493-521.

Jackson, J. Bradford, B. Stanko, E.A. and Hohl, K., 2012. Just authority? Public trust and police legitimacy. Oxford: Routledge.

Jarman, N., 2006. Peacebuilding and policing - The role of community based initiatives, Shared space: A research journal on peace, conflict and community relations in Northern Ireland, 3, 31-44. 
Kawalerowicz, J. and Biggs, M., 2015. Anarchy in the UK: Economic deprivation, social disorganization, and political grievance in the London riot of 2011, Social Forces 94(2), 673- 698.

Kirk, D. S. and Papachristos, A., 2011. Cultural mechanisms and the persistence of neighbourhood violence, American journal of sociology, 116(4), 1190-1233.

Kirk, D.S. and Matsuda, M., 2011. Legal cynicism, collective efficacy, and the ecology of arrest, Criminology, 49(2), 443-472.

Kwak, H. and McNeeley, S., 2017. Neighbourhood characteristics and confidence in the police in the context of South Korea, Policing and society, DOI: 10.1080/10439463.2017.1320997

Lawther, C., 2011. Unionism, truth recovery and the fearful past, Irish political studies, 26(3), 361-382.

Leonard, M. and McKnight, M., 2014. Bordering in transition: young people's experiences in 'post-conflict' Belfast, in S. Spyrou and M. Christou (eds.). Children and borders. Basingstoke: Palgrave Macmillan, 164-182.

Leonard, M. and McKnight, M., 2015. Traditions and Transitions: teenagers' perceptions of parading in Belfast, Children's Geographies, 13(4), 398-412.

Loader, I. and Mulcahy, A., 2003. Policing and the condition of England: Memory, politics and culture. Oxford: Oxford University Press.

MacGinty, R., 2006. No war, No peace. New York: Palgrave Macmillan.

McAlister, S. Scraton, P. and Haydon, D., 2009. Childhood in transition: Experiencing marginalization and conflict in Northern Ireland. Belfast: School of Law, Queen's University Belfast.

McEvoy, K. Gormally, B. and Mika, H., 2002. Conflict, crime control and the 're'- constitution of statecommunity relations in Northern Ireland, in G. Hughes, E. McLauglin and J. Muncie (eds.). Crime prevention and community safety: New directions. London: Sage, 182-212.

Merrilees, C. Taylor, K. Baird, R. Goeke-Morey, M., Shirlow, P. and Cummings, M., 2017. Neighbourhood effects of intergroup contact on change in youth intergroup bias, Journal of youth adolescence, doi $10.1007 / \mathrm{s} 10964-017-0648-6$

Mulcahy, A., 2006. Policing in Northern Ireland: Conflict, legitimacy and reform. Collumpton: Willan.

Mulcahy, A., 2008. Community policing in contested settings: The Patten report and police reform in Northern Ireland, in T. Williamson ed. The handbook of knowledge-based policing: Current conceptions and future directions. John Wiley and Sons: Chichester, 117-137.

Nolan, P., 2014. Northern Ireland peace monitoring report number three. Belfast: Community Relations Council.

Nolan, P. Bryan, D. Dwyer, C. Hayward, K. Radford, K. and Shirlow, P., 2014. The flag protest: an anatomy of a protest. Belfast: Queen's University, Belfast.

Northern Ireland Policing Board, 2016a. Annual policing plan for Northern Ireland 2016 - 17. Belfast: Northern Ireland Policing Board.

Northern Ireland Policing Board, 2016b. Public perceptions of the police, policing and community safety partnerships and the Northern Ireland Policing Board. Belfast: Northern Ireland Policing Board.

O'Rawe, M., 2003. Transitional policing arrangements in Northern Ireland: The can't and the won't of the change dialectic, Fordham international law journal, 26(4), 1015-73. 
Parades Commission for Northern Ireland 2016. Annual report and financial statements for the year ended $31^{\text {st }}$ March 2016. Belfast: PCNI / HMSO.

Pettigrew, T.F. and Tropp, L.R., 2006. The meta-analytic test of intergroup contact theory, Journal of personality and social psychology, 90(5), 751-783.

PytlikZillig, L. M. and Kimbrough, C. D., 2015. Consensus on conceptualizations and definitions of trust: Are we there yet?', in E. Shockley, T. Neal, L. PytlikZillig and B. Bornstein eds. Interdisciplinary perspectives on trust: Towards theoretical and methodological integration. New York: Springer, 17-47.

Police Service of Northern Ireland, 2011. What do you want most from your police service? Available from: http://www.psni.police.uk/psni_commitments_mailer.pdf [Accessed 24 July 2017]

Police Service of Northern Ireland, 2017. Workforce composition statistics.

Available from: https://www.psni.police.uk/inside-psni/Statistics/workforce-composition- statistics/ [Accessed 24 July 2017].

Sampson, R., 2012. Great American city. Chicago: University of Chicago Press.

Sampson, R. and Bartusch, D., 1998. Legal cynicism and (subculture?) Tolerance of deviance: The neighbourhood context of racial differences, Law and society review 32(4), 777-804.

Sampson, R. and Morenoff, J.D., 1997. Durable inequality: Spatial dynamics, social processes and the persistence of poverty in Chicago neighbourhoods, in S. Bowles, S. Durlauf and K. Hoff, K. eds. Poverty traps. Princeton: Princeton University Press, 176-203.

Seymour, D., 2017. Report of the independent reviewer justice and security (Northern Ireland) act ninth report $1^{\text {st }}$ August $2015-31^{\text {st } J u l y ~ 2016 . ~ L o n d o n: ~ H M S O . ~}$

Shirlow, P. and Murtagh, B., 2006. Belfast: Segregation, violence and the city. London: Pluto Press.

Stoutland, S. E. 2001. The multiple dimensions of trust in resident/police relations in Boston, Journal of research in crime and delinquency, 38(3), 226-256.

Tam, T. Hewstone, M. Kenworthy, J. and Cairns, E., 2009. Intergroup trust in Northern Ireland, Personality and social psychology bulletin, 35(1), 45-59.

Tankebe, J., 2009. Public cooperation with the police in Ghana: Does procedural fairness matter?, Criminology 47(4), 1265-1293.

Taylor, L. Townsend, D. Merrilees, C. Goeke-Morey, M. Shirlow, P. and Cummings, E., 2017. Adolescent Civic Engagement and Perceived Political Conflict, Youth and Society, doi 10.1177/0044118X17697236

Thomassen, G. and Kääriänen, J., 2016. System satisfaction, contact satisfaction and trust in the police, European journal of policing studies, 4(3), 437-448.

Topping, J. R., 2008a. Community policing in Northern Ireland: A resistance narrative, Policing and society, 18(4), 377-396.

Topping, J. R., 2008b. Diversifying from within: Community policing and the governance of security in Northern Ireland, British journal of criminology, 48(6), 778-797.

Topping, J. R., 2009. Beyond the Patten report: The governance of security in policing with the community. Thesis (PhD). Ulster University. 
Topping, J. R., 2015. Policing in transition, in C. Dwyer and A. McAlinden eds. Criminal justice in transition: The Northern Ireland context. Oxford: Hart Publishing, 109-130.

Topping, J. R., 2016. Accountability, policing and the PSNI: Leading globally, limited locally?, in S. Lister, and M. Rowe, eds. Accountability and policing. Oxon: Routledge, 150- 171.

Topping, J. and Byrne, J., 2012a. Paramilitary punishments in Belfast: Policing beneath the peace, Journal of the behavioural sciences of terrorism and political aggression, 4(1), 41-59.

Topping, J.R. and Byrne, J., 2012b. Policing, terrorism and the conundrum of community: A Northern Ireland perspective, in B. Spalek, Counter-terrorism: Community-based approaches to terror crime. Basingstoke: Palgrave, 157-180.

Topping, J. R. and Byrne, J., 2016. Shadow policing: The boundaries of community based Policing and society, 26(5), 522-543.

Weisburd, D. Groff, E.R. and Yang, S-M., 2012. The criminology of place. Oxford: Oxford University Press.

Wilson, R., 2016. Northern Ireland peace monitoring report number 4. Belfast: Northern Ireland Community Relations Council / The Joseph Rowntree Charitable Trust. 
Table 1

Correlation matrix for key variables

\begin{tabular}{|c|c|c|c|c|c|c|c|c|c|}
\hline & 1 & 2 & 3 & 4 & 5 & 6 & 7 & 8 & 9 \\
\hline Trust in police fairness and engagement (1) & 1 & & & & & & & & \\
\hline Trust in police effectiveness (2) & $0.82^{*}$ & 1 & & & & & & & \\
\hline Ethno-religious diversity ( 3 ) & $0.14^{*}$ & $0.10^{*}$ & 1 & & & & & & \\
\hline Concentrated disadvantage (4) & $-0.14^{*}$ & $-0.14 *$ & $-0.11^{*}$ & 1 & & & & & \\
\hline Crime and disorder (5) & $0.07^{*}$ & $0.07^{*}$ & $-0.16^{*}$ & $-0.62 *$ & 1 & & & & \\
\hline Institutional density (6) & -0.04 & -0.04 & $-0.10^{*}$ & $0.38^{*}$ & $-0.29 *$ & 1 & & & \\
\hline Population density (7) & 0.01 & 0.01 & $0.08^{*}$ & $0.55^{*}$ & $-0.58^{*}$ & $0.13^{*}$ & 1 & & \\
\hline Community Prioritisation Index (CPI) (8) & $0.11^{*}$ & $0.11^{*}$ & $0.33^{*}$ & $-0.74 *$ & $0.53^{*}$ & $-0.37^{*}$ & $-0.48^{*}$ & 1 & \\
\hline Perceived disorder (9) & $-0.15^{*}$ & $-0.09 *$ & -0.04 & $0.22^{*}$ & $-0.30^{*}$ & $0.10^{*}$ & $0.28 *$ & $-0.25^{*}$ & 1 \\
\hline
\end{tabular}


Table 2

Multi-level linear regression models predicting trust in police fairness and community engagement

\begin{tabular}{|c|c|c|c|c|c|c|c|c|c|}
\hline & & Model 1 & & & Model 2 & & & Model 3 & \\
\hline & B & 95\% C.I. & $\begin{array}{l}\text { Std. } \\
\beta\end{array}$ & $\beta$ & 95\% C.I. & $\begin{array}{l}\text { Std. } \\
\beta \\
\end{array}$ & B & 95\% C.I. & Std. B \\
\hline \multicolumn{10}{|l|}{ Area level predictors } \\
\hline Ethno-religious diversity & $0.79^{*}$ & $0.18,1.40$ & 0.13 & $0.61+$ & $-0.03,1.25$ & 0.1 & -0.38 & $-1.60,0.84$ & -0.06 \\
\hline Concentrated disadvantage & $-1.40^{*}$ & $-2.48,-0.32$ & -0.17 & $-1.24 *$ & $-2.29,-0.19$ & -0.15 & $-1.26^{*}$ & $-2.29,-0.22$ & -0.15 \\
\hline Crime and disorder & 0.00 & $-0.00,0.00$ & 0.05 & 0.00 & $-0.00,0.00$ & 0.02 & 0.00 & $-0.00,0.00$ & 0.01 \\
\hline Institutional density & 0.07 & $-0.06,0.20$ & 0.04 & 0.07 & $-0.06,0.20$ & 0.05 & 0.07 & $-0.05,0.20$ & 0.05 \\
\hline CPI & 0.00 & $-0.00,0.00$ & 0.05 & 0.00 & $-0.00,0.00$ & -0.03 & 0.00 & $-0.00,0.00$ & -0.01 \\
\hline Population density & $0.003^{*}$ & $-0.00,0.01$ & 0.11 & $0.034 * *$ & $0.00,0.01$ & 0.13 & $0.004^{* *}$ & $0.00,0.01$ & 0.14 \\
\hline \multicolumn{10}{|l|}{ Contentious parade (ref: no) } \\
\hline Yes & 0.09 & $-0.11,0.30$ & -0.04 & 0.15 & $-0.04,0.35$ & 0.07 & 0.14 & $-0.05,0.34$ & 0.06 \\
\hline \multicolumn{10}{|l|}{ Individual level predictors } \\
\hline Perceived disorder & & & & $-0.14 * * *$ & $-0.21,-0.06$ & -0.13 & $-0.13^{* * *}$ & $-0.21,-0.06$ & -0.13 \\
\hline Age & & & & $0.01^{* *}$ & $0.00,0.01$ & 0.13 & $0.01 * *$ & $0.00,0.01$ & 0.13 \\
\hline \multicolumn{10}{|l|}{ Gender (ref: male) } \\
\hline Female & & & & $0.14^{* *}$ & $0.04,0.24$ & 0.09 & $0.14^{* *}$ & $0.04,0.24$ & 0.09 \\
\hline \multicolumn{10}{|l|}{ Religion (ref: Protestant) } \\
\hline Catholic & & & & -0.05 & $-0.19,0.09$ & -0.03 & $-0.70^{*}$ & $-1.38,-0.03$ & -0.44 \\
\hline Other/none & & & & -0.07 & $-0.21,0.08$ & -0.03 & -0.39 & $-1.29,0.50$ & -0.19 \\
\hline \multicolumn{10}{|c|}{ Economic activity status (ref: employed) } \\
\hline "Homemaker"/retired & & & & $-0.14+$ & $-0.30,0.01$ & -0.09 & $-0.15+$ & $-0.30,0.01$ & -0.09 \\
\hline Student & & & & 0.01 & $-0.20,0.22$ & 0 & 0.02 & $-0.20,0.23$ & 0.01 \\
\hline Unemployed & & & & $-0.22 * *$ & $-0.39,-0.05$ & -0.09 & $-0.22 * *$ & $-0.39,-0.06$ & -0.09 \\
\hline \multicolumn{10}{|l|}{ Social class (ref: C2DE) } \\
\hline $\mathrm{ABC} 1$ & & & & $0.10+$ & $-0.01,0.21$ & 0.06 & $0.10+$ & $-0.01,0.20$ & 0.06 \\
\hline \multicolumn{10}{|l|}{ Interaction effect } \\
\hline Catholic * diversity & & & & & & & $1.23+$ & $-0.00,2.46$ & 0.36 \\
\hline Other/none * diversity & & & & & & & 0.58 & $-1.03,2.18$ & 0.16 \\
\hline Constant & $2.62^{*}$ & $0.03,5.21$ & & 2.07 & $-0.45,4.60$ & & $2.64^{*}$ & $0.07,5.22$ & \\
\hline ICC & 0.11 & & & 0.09 & & & 0.08 & & \\
\hline $\mathrm{R}^{2}$ - within & 0.05 & & & 0.05 & & & 0.05 & & \\
\hline $\mathrm{R}^{2}$ - between & 0.08 & & & 0.08 & & & 0.09 & & \\
\hline $\mathrm{R}^{2}$ - overall & 0.09 & & & 0.09 & & & 0.09 & & \\
\hline $\mathrm{N}$ & 914 & & & 914 & & & 914 & & \\
\hline
\end{tabular}

$+\mathrm{p}<.1, * \mathrm{p}<.05, * * \mathrm{p}<.01, * * * \mathrm{p}<.001$ 
Table 3

Multi-level linear regression models predicting trust in police effectiveness

\begin{tabular}{|c|c|c|c|c|c|c|c|c|c|}
\hline & \multicolumn{3}{|c|}{ Model 1} & \multicolumn{3}{|c|}{ Model 2} & \multicolumn{3}{|c|}{ Model 3} \\
\hline & B & 95\% C.I. & Std. $\beta$ & $\beta$ & $95 \%$ C.I. & Std. $\beta$ & B & 95\% C.I. & Std. $\beta$ \\
\hline \multicolumn{10}{|l|}{ Area level predictors } \\
\hline Ethno-religious diversity & 0.52 & $-0.13,1.16$ & 0.08 & 0.53 & $-0.12,1.18$ & 0.08 & -0.66 & $-1.92,0.59$ & -0.1 \\
\hline Concentrated disadvantage & $-1.62 * *$ & $-2.75,-0.48$ & -0.19 & $-1.40^{*}$ & $-2.47,-0.33$ & -0.16 & $-1.42 * *$ & $-2.48,-0.37$ & -0.17 \\
\hline Crime and disorder & 0.00 & $-0.00,0.00$ & 0.04 & 0.00 & $-0.00,0.00$ & 0.04 & 0.00 & $-0.00,0.00$ & 0.03 \\
\hline Institutional density & 0.08 & $-0.06,0.22$ & 0.05 & 0.07 & $-0.05,0.20$ & 0.05 & 0.08 & $-0.05,0.21$ & 0.05 \\
\hline CPI & 0.00 & $-0.00,0.00$ & -0.03 & 0.00 & $-0.00,0.00$ & -0.03 & 0.00 & $-0.00,0.00$ & -0.01 \\
\hline Population density & $0.004^{*}$ & $0.00,0.01$ & 0.15 & $0.004 * *$ & $0.00,0.01$ & 0.15 & $0.004^{* *}$ & $0.00,0.01$ & 0.16 \\
\hline \multicolumn{10}{|l|}{ Contentious parade (ref: no) } \\
\hline Yes & 0.03 & $-0.18,0.25$ & 0.01 & 0.04 & $-0.16,0.24$ & 0.02 & 0.03 & $-0.17,0.22$ & 0.01 \\
\hline \multicolumn{10}{|l|}{ Individual level predictors } \\
\hline Perceived disorder & & & & $-0.07+$ & $-0.15,0.01$ & -0.07 & $-0.07+$ & $-0.15,0.01$ & -0.06 \\
\hline Age & & & & $0.00+$ & $-0.00,0.01$ & 0.09 & $0.00+$ & $-0.00,0.01$ & 0.09 \\
\hline \multicolumn{10}{|l|}{ Gender (ref: male) } \\
\hline Female & & & & 0.06 & $-0.05,0.16$ & 0.04 & 0.06 & $-0.05,0.16$ & 0.03 \\
\hline \multicolumn{10}{|l|}{ Religion (ref: Protestant) } \\
\hline Catholic & & & & 0.01 & $-0.14,0.15$ & 0 & $-0.77 *$ & $-1.47,-0.07$ & -0.46 \\
\hline Other/none & & & & -0.07 & $-0.22,0.09$ & -0.03 & -0.55 & $-1.49,0.39$ & -0.26 \\
\hline \multicolumn{10}{|c|}{ Economic activity status (ref: employed) } \\
\hline "Homemaker"/retired & & & & $-0.15+$ & $-0.32,0.02$ & -0.08 & $-0.15+$ & $-0.32,0.02$ & -0.09 \\
\hline Student & & & & -0.02 & $-0.25,0.20$ & -0.01 & -0.02 & $-0.25,0.20$ & -0.01 \\
\hline Unemployed & & & & $-0.23^{*}$ & $-0.40,-0.05$ & -0.09 & $-0.23 *$ & $-0.41,-0.05$ & -0.09 \\
\hline \multicolumn{10}{|l|}{ Social class (ref: C2DE) } \\
\hline $\mathrm{ABC} 1$ & & & & $0.13^{*}$ & $0.02,0.24$ & 0.08 & $0.13^{*}$ & $0.01,0.24$ & 0.08 \\
\hline \multicolumn{10}{|l|}{ Interaction effects } \\
\hline Catholic * diversity & & & & & & & $1.47^{*}$ & $0.18,2.75$ & 0.41 \\
\hline Other/none * diversity & & & & & & & 0.86 & $-0.83,2.55$ & 0.23 \\
\hline Constant & $3.23^{*}$ & $0.51,5.96$ & & $2.54+$ & $-0.04,5.12$ & & $3.24^{*}$ & $0.61,5.87$ & \\
\hline ICC & 0.11 & & & 0.07 & & & 0.06 & & \\
\hline $\mathrm{R}^{2}$ - within & 0 & & & 0.02 & & & 0.02 & & \\
\hline $\mathrm{R}^{2}$ - between & 0.06 & & & 0.09 & & & 0.10 & & \\
\hline $\mathrm{R}^{2}$ - overall & 0.03 & & & 0.06 & & & 0.07 & & \\
\hline $\mathrm{N}$ & 914 & & & 914 & & & 914 & & \\
\hline
\end{tabular}

$+\mathrm{p}<.1,{ }^{*} \mathrm{p}<.05,{ }^{* *} \mathrm{p}<.01,{ }^{* * *} \mathrm{p}<.001$ 
Figure 1: Trust in the Police Service of Northern Ireland

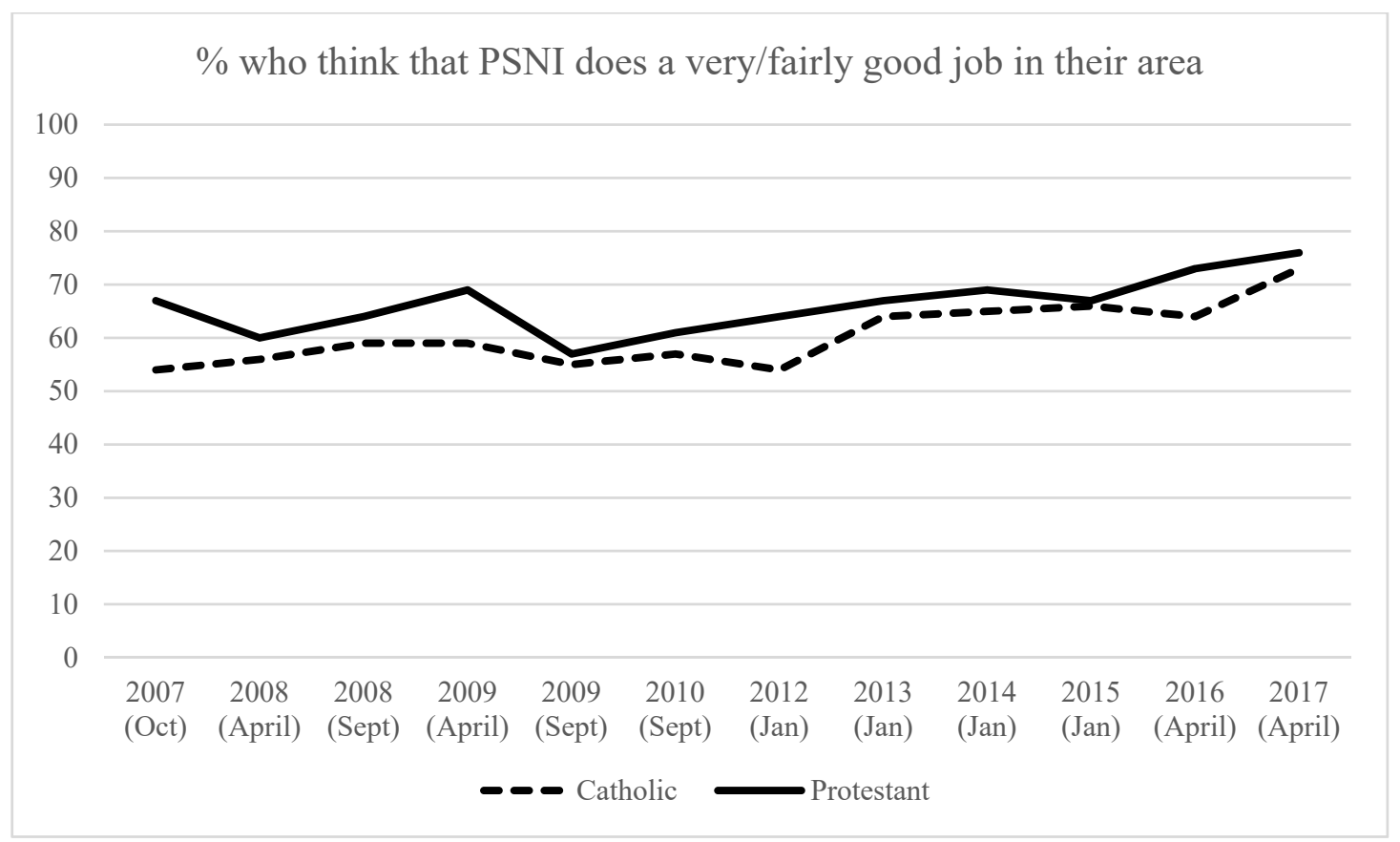


Figure 2: Interaction between individual level religion and area level diversity

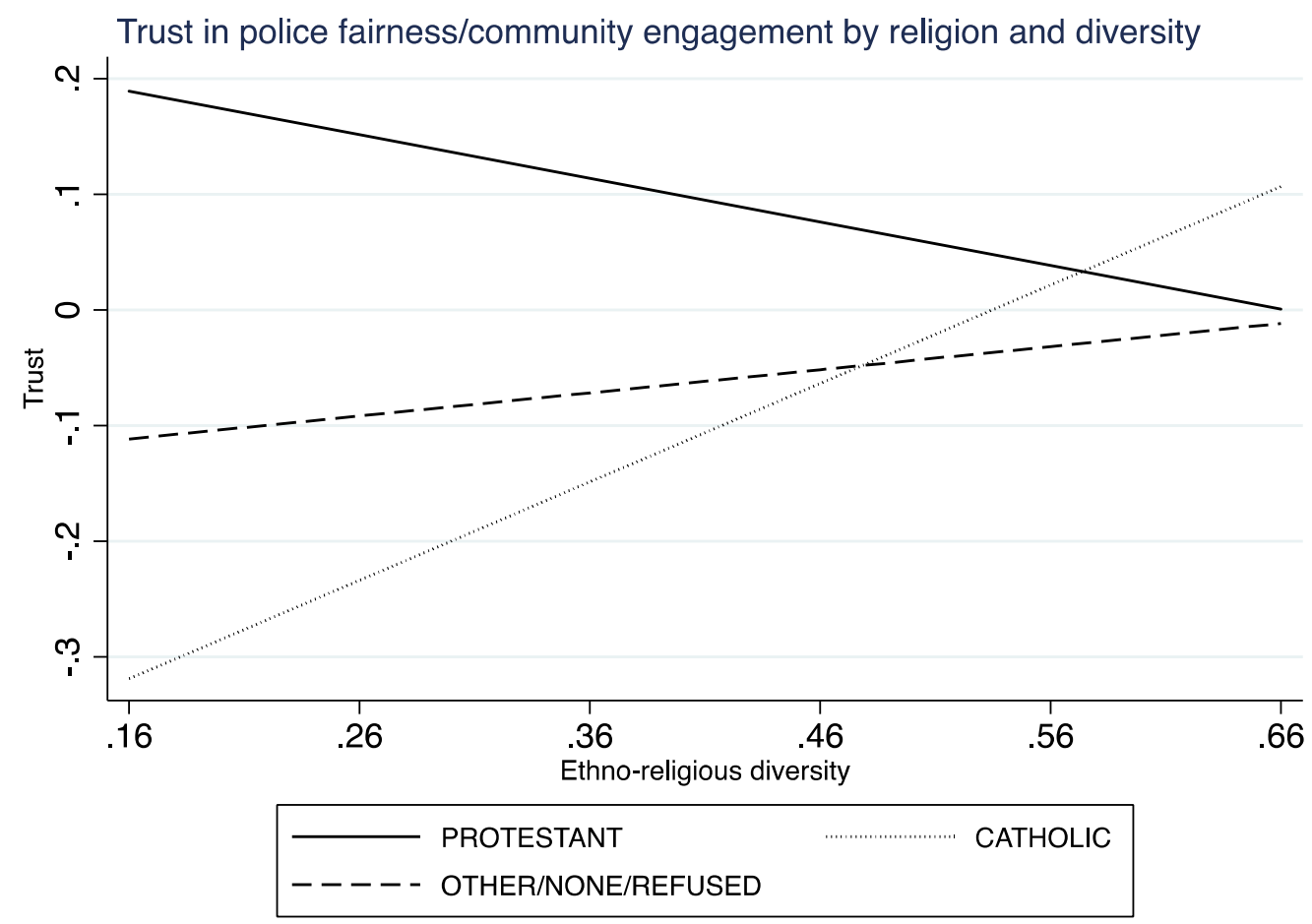

Figure 3: Interaction between individual level religion and area level diversity

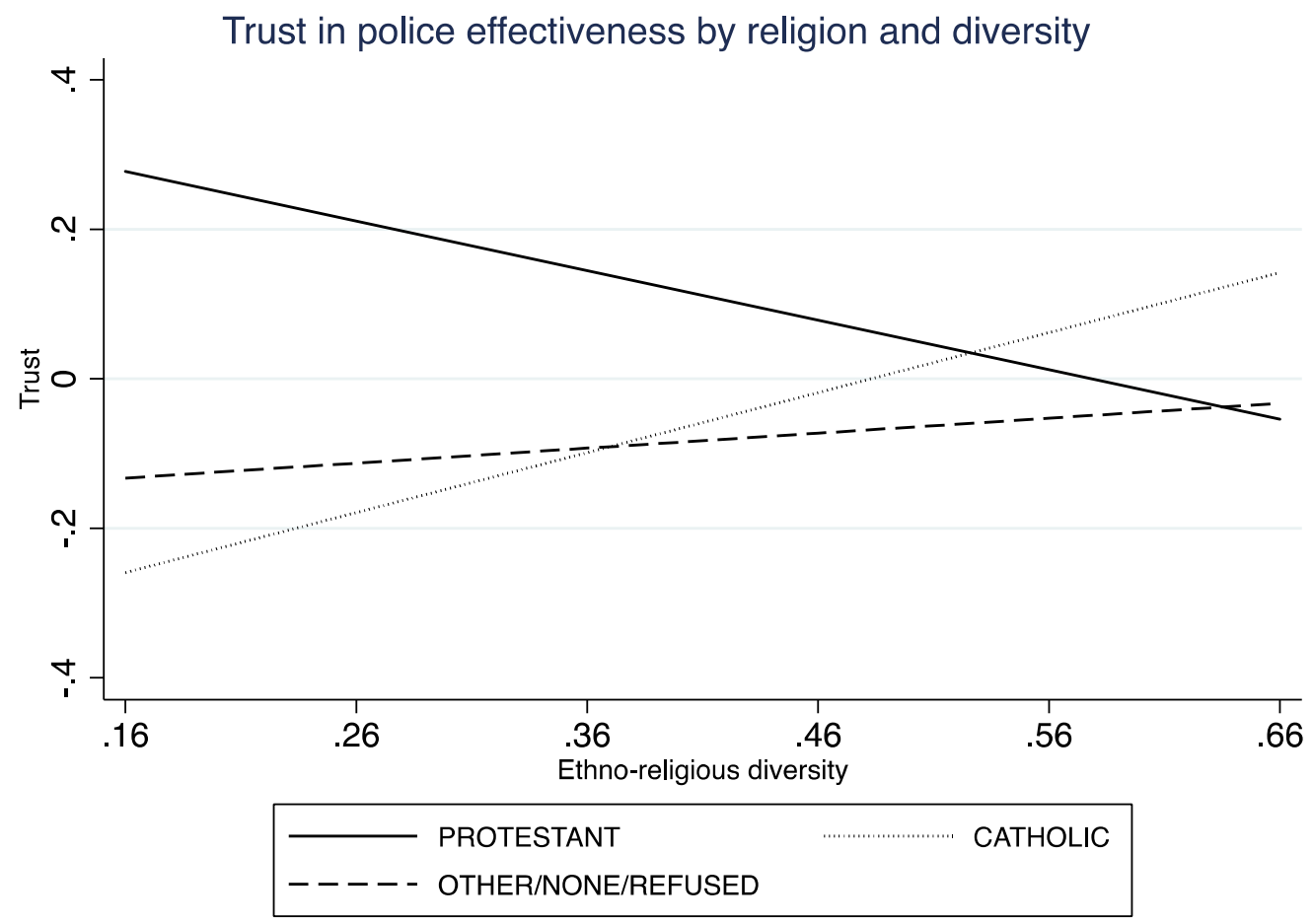


Figure 4: Interaction between institutional density and diversity at the area level

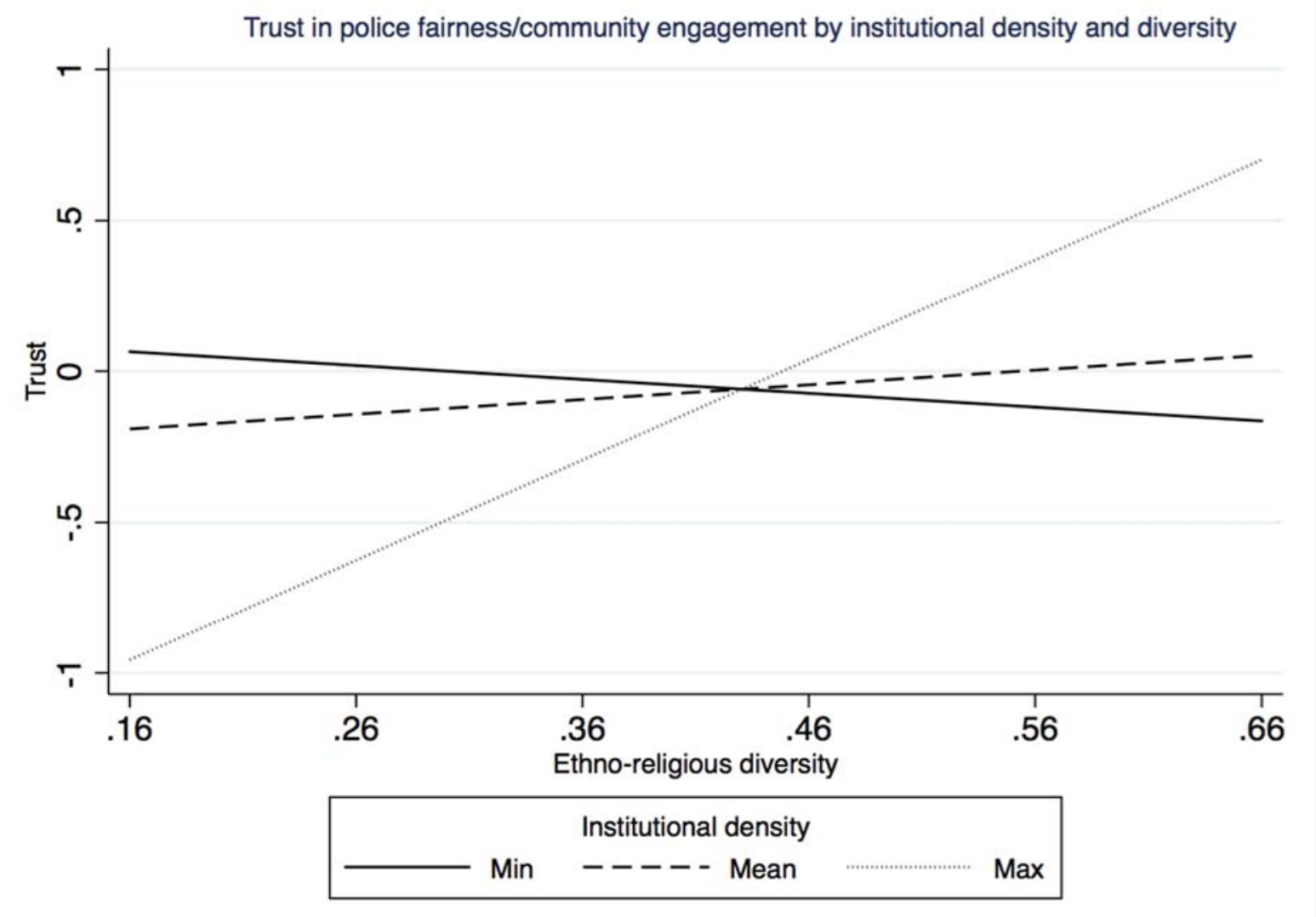


Appendix Table 1: Latent constructs and measures

\begin{tabular}{|c|c|c|}
\hline & $\begin{array}{r}\text { Std. } \\
\text { factor } \\
\text { loading }\end{array}$ & $R^{2}$ \\
\hline \multicolumn{3}{|l|}{ Trust in police fairness and community engagement ${ }^{1}$} \\
\hline \multicolumn{3}{|l|}{ To what extent do you agree that the local police ... } \\
\hline Would treat you with respect & 0.81 & 0.66 \\
\hline Treat everyone fairly regardless of who they are & 0.83 & 0.70 \\
\hline Are friendly and approachable & 0.83 & 0.68 \\
\hline Are helpful & 0.85 & 0.72 \\
\hline Cab be relied on to be there when you need them & 0.89 & 0.80 \\
\hline Understand the issues that affect this community & 0.91 & 0.83 \\
\hline Are dealing with the things that matter this community & 0.94 & 0.88 \\
\hline Listen to the concerns of local people & 0.95 & 0.91 \\
\hline \multicolumn{3}{|l|}{ Trust in police effectiveness ${ }^{2}$} \\
\hline \multicolumn{3}{|l|}{ How well do you think the PSNI ... } \\
\hline Respondents to emergencies promptly & 0.87 & 0.75 \\
\hline Provides a visible patrolling presence & 0.68 & 0.47 \\
\hline Tackles serious crime & 0.88 & 0.77 \\
\hline Supports victims and witness of crime & 0.91 & 0.83 \\
\hline Deals with public disorder, including street protests and riots & 0.81 & 0.66 \\
\hline Tackles drug dealing and use & 0.83 & 0.69 \\
\hline Tackles dangerous driving & 0.77 & 0.59 \\
\hline \multicolumn{3}{|l|}{ Perceived disorder ${ }^{3}$} \\
\hline \multicolumn{3}{|l|}{ How much of a problem in this area is/are ... } \\
\hline Teenagers hanging around on the streets & 0.87 & 0.76 \\
\hline Rubbish or litter lying around & 0.74 & 0.55 \\
\hline Vandalism, graffiti and other deliberate damage to property & 0.86 & 0.75 \\
\hline People being drunk or rowdy in public places & 0.92 & 0.85 \\
\hline \multicolumn{3}{|l|}{ Fit statistics } \\
\hline Chi square & 527.8 & \\
\hline Degrees of freedom & 137 & \\
\hline $\mathrm{p}$-value & $<0.0005$ & \\
\hline RMSEA & 0.05 & \\
\hline $\mathrm{CFI}$ & 0.99 & \\
\hline TLI & 0.99 & \\
\hline
\end{tabular}

1. Mean $=-.02 ; \mathrm{SD}=.78 ; \operatorname{Min}=-2.33 ; \operatorname{Max}=1.82$

2. $\operatorname{Mean}=-.02 ; \mathrm{SD}=.81 ; \operatorname{Min}=-2.39 ; \operatorname{Max}=2.05$

3. Mean $=.01 ; \mathrm{SD}=.79 ; \operatorname{Min}=-2.40 ; \operatorname{Max}=1.89$ 
